\title{
Budget and Financial Management Office
}

National Cancer Institute

\section{Source}

National Cancer Institute. Budget and Financial Management Office. NCI Thesaurus.

Code C19207.

Responsible for a broad range of Office of the Director strategic and financial management activities. 